\title{
XLVIII. On the diurnal periodicity of earthguakes
}

\section{Charles Davison Sc.D. F.G.S.}

To cite this article: Charles Davison Sc.D. F.G.S. (1896) XLVIII. On the diurnal periodicity of earthguakes, Philosophical Magazine Series 5, 42:259, 463-476, DOI: 10.1080/14786449608620942

To link to this article: http://dx.doi.org/10.1080/14786449608620942

曲 Published online: 08 May 2009.

Submit your article to this journal

Џ Article views: 2

Q View related articles $\sqsubset$ 
velocity of electromagnetic waves are not greatly changed (i.e. not at all within our experimental limits) by the Röntgen radiation, and this applies alike together in air and in benzene.

(5) A selenium cell composed of platinum electrodes and highly purified selenium is affected by Röntgen radiation to an extent which is comparable with the effect produced by diffused daylight.

(6) No permanent or temporary electromotive force is set up in a selenium cell by the Röntgen radiation.

XLVIII. On the Diurnal Periodicity of Earthquakes. By Charles Davison, Sc.D., F.G.S., Mathematical Master at King Edward's High School, Birmingham*.

1. WV ITHIN the last seren years, two important memoirs have appeared dealing in part with the diurnal periodicity of earthquakes. In a paper published in 1889 , M. de Montessus de Ballore $†$ considers the question from a negative point of view, his object being to show that the diurnal period is apparent rather than real. More recently, in 1894 , Prof. $\mathrm{F}$. Omori $\ddagger$, in a valuable investigation on the after-shocks of earthquakes, points out that there are various periodic fluctuations in their decline of frequency, three of the periods being a day or less in length. I will first give a brief summary of the methods and conclusions of these two writers before proceeding with the immediate object of this paper, which is to subject the records used by them, or similar records, to the more rigid process of harmonic analysis.

2. M. de Montessus's statistical inquiries are based on a great catalogue of more than 45,000 earthquakes. The separate entries being of unequal value, he divides them into seven elasses, according to the nature of the district and the mode of record. The first six classes include all registers obtained without instrumental aid, the seventh those of the Italian geodynamic observatories. For every region of each class he gives the total number of shocks during each hour of the day. Representing by $d$ the number of shocks occurring in the twelve day-hours ( 6 A.M. to 6 P.M. $)$, and by $n$ the number in the twelve night-hours (6 P.M. to 6 A.M.), he then evaluates the ratio $d / n$ for each region. For the first group, excluding the fifth or volcanic series, the mean value of $d / n$

* Communicated by the Author, with some alterations, after being read before the Royal Society on March 5, 1896.

† “Etudes sur la répartition horaire diurne-nocturne des Séismes et leur prétendue relation avee les culminations de la lune." Arch. des Sc. phys. et nat, vol. xxii. 1889, pp. 409-430 and tables.

$\ddagger$ "On the After-shocks of Earthquakes." Journal of the Coll. of Science, Imp. Univ. Japan, vol. vii. 1894, pp. 111-200. 
varies from 0.75 to 0.82 , and increases with the scientific character of the record. Also, the value of $d / n$ being small for moderate shocks and approaching unity for severe ones, M. de Montessus infers that earthquakes in reality occur just as frequently by day as by night.

The seventh class comprises the records from thirteen geodynamic observatories in Italy, all obtained by means of continuously recording instruments. The value of $d / n$ varies from 0.50 for Corleone to 2.06 for Bologna and S. Tuaca, being on an average $\mathrm{I} \cdot 49$. If all shocks are excluded but those of intensity I. of the Rossi-Forel scale, the mean value rises to 1.80 . This seems to imply the existence of a true diu "nal period, but M. de Montessus interprets the inequality otherwise, referring the more numerous slight sbocks of the day-time to "mouvenents dus à l'homme, roulements de voitures et de trains de chemins de fer, explosions de mines, \&c." The suggestion is a useful oire and deserves careful consideration. At the same time, it should be remarked that the phenomena admit of another explanation, for we might expect that slight earthquakes would be subject to periods of greater amplitude than violent shocks *. With regard to the non-instrumental records, however, M. de Montessus's analysis leaves little doubt that the more frequent observation of earthquakes at night is due to the conditions being then more favourable for the detection of weak tremors.

3. Prof. Omori's investigation is based for the most part on seismometric records. He makes use of the valuable Tokio register from 1876 to 1893 , that for all Japan from 1885 to 1890 (which is only in part a seismometric record), and especially the lists of after-shocks at Kumamoto, Gifu and Nagoya, and Chiran, during the thirteen or fourteen days following the Kumamoto eartluquae of 1889 , the Mino-Owari earthquake of 1891 , and the Kagoshima earthquake of 1893 . The shocks are grouped in hourly, two-hourly, and six-hourly intervals, and eurves are drawn, not through the points corresponding to the numbers so obtained, but by some process of smoothing which is not explained. The periods which are brought into prominence by this method are 24 hours, about 8 or 9 hours, and about 4 hours, in length. In the case of the Mino-Owari earthquakes, while both the eighthourly and four-hourly periods are shown on the Gifu and Nagoya curves, the former is more marred at Gifu and the latter at Nagoya. The diurnal period for these two stations appears to have its maximum about 1 A.M., for Tokio in the evening, and for all Japan early in the morning.

4. The method adopted in this paper is that of harmonic

* See Phil. Trans. 1893 A, pp. 1116-1120. 
analysis. As the absolute frequency of earthquakes in different districts is extremely variable, the average number of shocks per hour in each case is represented by unity, so that the results may be directly comparable. The epochs are given in the mean local time of the place of observation, with two exceptions, namely, Japan and Italy, in which the standard times are those of $135^{\circ} \mathrm{E}$. and $15^{\circ} \mathrm{E}$. respectively. In the Table, however, the figures for Japan refer to mean Tokio time, for Japanese after-shocks to mean time of $135^{\circ} \mathrm{E}$., and for the Italian stations to mean Rome time.

\section{Japan.}

5. Tokio.-Japan Seismol. Soc. Trans. vol. ii., 1880, pp. 4-14, 39 ; vol. vi., 1883, pp. 32-35 ; vol. viii., 1885, pp. 100-108; vol. x., 1887, pp. 97-99; vol. xv., 1890, pp. 127-134 : Brit. Assoc. Rep. 1886, pp. 414-415; 1887, pp. 212-213; 1888, pp. 435-137 ; 1889, pp. 295-296; 1890, pp. 160-162 ; 1891, pp. $123-124$; 1892, pp. $9 \ddot{3}-95 ; 1893$, pp. 214-215.

Duration of record, 1876-1881 and 1883-1892. Number of earihquakes, 1204 ; in winter, $6 \mathrm{E} 1$; in summer, 543.

This valuable record begins in the latter half of 1872 , and, up to the end of 1892, contains 1304 entries. From the end of 1875 , the earthquakes were registered by means of seismographs, Palmieri's being in use until April 1885, and the Gray-Milne seismograph after that date. Towards the closo of $\mathbf{1 . 8 8 2}$ the list is incomplete, owing to the removal of the instrument to a new station. For general purposes this would be of little account; but as I wished to compare the results oblained from the six winter months (October to March) with those obtained from the six summer months (April to September), this year has been omitted.

\begin{tabular}{|c|c|c|c|c|c|c|}
\hline \multirow{2}{*}{$\begin{array}{l}\text { Harmonic } \\
\text { Component. }\end{array}$} & \multicolumn{2}{|c|}{ Whole year. } & \multicolumn{2}{|c|}{ Winter. } & \multicolumn{2}{|c|}{ Summer. } \\
\hline & Ampl. & $\begin{array}{l}\text { Epoch. } \\
\text { h m }\end{array}$ & Ampl. & $\begin{array}{l}\text { Epoch. } \\
\mathrm{h} \text { m }\end{array}$ & Ampl. & $\begin{array}{c}\text { Epoch. } \\
\mathbf{h} \text { m }\end{array}$ \\
\hline 1st ( 24 hours) ... & $\cdot 130$ & $\begin{array}{c}\text { A.M. } \\
1014\end{array}$ & .093 & $\begin{array}{r}\text { A.M. } \\
1039\end{array}$ & $\cdot 176$ & $\begin{array}{l}\text { A.M. } \\
958\end{array}$ \\
\hline 2nd (12 hours) ... & $\cdot 08 \cdot 2$ & 1022 & $\cdot 123$ & 926 & .085 & 012 \\
\hline 3rd (8 hours) & .098 & 628 & $\cdot 086$ & 631 & $\cdot 111$ & 625 \\
\hline 4th (6 hours) & $\cdot 118$ & 37 & $\cdot 143$ & 256 & $\cdot 096$ & 326 \\
\hline 5 th (4 $4 \frac{4}{5}$ hours) ... & $\cdot 030$ & 18 & $\cdot 059$ & 149 & .060 & 42 \\
\hline 6th (4 hours)... & $\cdot 024$ & 327 & .097 & 311 & .058 & 058 \\
\hline
\end{tabular}


6. Japen.-Prof. J. Milne, "A Catalogue of 8331 Earthquakes recorded in Japan between 1885 and 1892." Seismol. Journ. of Japan, vol. iv. 1895, pp. i-xxi., 1-367.

Duration of record, 1885-1890. Number of earthquakes, 1175 ; in winter, 578 ; in summer, 597.

Prof. Milne's great catalogue includes all the earthquakerecords collected by the Imperial Meteorological Office at Tokio. A large number of these were obtained by means of seismographs, but unfortunately the particular shocks so recorded are not indicated. For my present purpose, I have made use only of those in which the time of occurrence is given in hours, minutes, and seconds : for these, Prof. Milne informs me, were certainly registered by seismographs. As many others may, however, be omitted by this mode of selection, it is obvious that the results will not compare in value with those obtained from the Tokio record. I have excluded the shocks occurring during the last two years embraced by the catalogue on account of the great number that followed the Mino-Owari earthquake of 1891 (see $\$ \S 7,8)$ :-

\begin{tabular}{|c|c|c|c|c|c|c|}
\hline \multirow{2}{*}{$\begin{array}{l}\text { Hammonic } \\
\text { Component. }\end{array}$} & \multicolumn{2}{|c|}{ Whole sear. } & \multicolumn{2}{|c|}{ Winter. } & \multicolumn{2}{|c|}{ Summer. } \\
\hline & Ampl. & $\begin{array}{l}\text { Epoch. } \\
\mathbf{h} \mathrm{m}\end{array}$ & Ampl. & $\underset{\mathrm{h} \text { ill }}{\mathrm{E}_{\text {ros }} .}$ & Anupl. & $\underset{\text { Epcih. }}{\text { him }}$ \\
\hline 1st ( 24 hours) ... & $\cdot 147$ & $\begin{array}{l}\text { A.M. } \\
1153\end{array}$ & $\cdot 239$ & 1150 & .061 & $\begin{array}{ll}\text { P.N. } & \\
0 & 2\end{array}$ \\
\hline 2 nd ( 12 hours) ... & .004 & 98 & 035 & 948 & .028 & $\begin{array}{l}\text { A.M. } \\
358\end{array}$ \\
\hline 3rd (8 hours) & .064 & 631 & .045 & 612 & .083 & 640 \\
\hline 4th (6 hours) $\ldots$ & $\cdot 100$ & 239 & 067 & 28 & $\cdot 146$ & 253 \\
\hline
\end{tabular}

After-Shocks of Japanese Larthquakes.

7. Prof. F. Onsori, Journal of the College of Science, Imp. Univ., Japan, vol. vii., 1894, pp. 126-138, 157, 178-191, 194. I an indebted to Mr. K. Nakamura, Director of the Central Meteorological Office, Tokio, for the hourly numbers of shocks recurded during each month by a Gray-niline seismograph at Gifu from October 1891 to December 1893, and at Nemuro from March 1894 to February 1895.

Duration of records : Kumamoto, July 31-Aug. 13, 1889; Gifu and Nagoya*, Oct. 29-Nov. 10, 1891 ; Chiran, Sept. 8-21, 1893 ; Nemuro, March 1894. Number of earthquakes:

* It should be mentioned that a few of the hourly numbers of shocks at Gifu and Nagoya given in the table differ by one or two units from those given by Prof. Omori. The figures in the table are obtained from the lists of shochs given in Prof. Omoris tables xi. and xii. 
Kumamoto, 148 ; Gifu, 1258 ; Nagoya, 572; Chiran, 233 ; Nemuro, 345.

The Kumamoto earthquake occurred on July 28, 1889 ; the Mino-Owari earthquake un October 28, 1891 ; the Kagoshima earthquake on September 7, 1893; and the Nemuro earthquake on March 22, 1894.

\begin{tabular}{|c|c|c|c|c|c|c|c|c|c|c|}
\hline \multirow{2}{*}{$\begin{array}{l}\text { Harmonic } \\
\text { Components. }\end{array}$} & \multicolumn{2}{|c|}{ Kumamoto. } & \multicolumn{2}{|c|}{ Gifu. } & \multicolumn{2}{|c|}{ Nagroya. } & \multicolumn{2}{|c|}{ Cbiran. } & \multicolumn{2}{|c|}{ Neinuro. } \\
\hline & Anpl. & $\begin{array}{c}\text { Epoch. } \\
\mathrm{h}\end{array}$ & Ampl. & $\begin{array}{c}\text { Epoch. } \\
\text { h }\end{array}$ & Ampl. & $\begin{array}{l}\text { Epoch } \\
\text { h m }\end{array}$ & Ampl. & $\begin{array}{c}\text { Epoch. } \\
\text { h m }\end{array}$ & Ampl. & $\begin{array}{c}\text { Epoch. } \\
\text { h } \mathrm{m}\end{array}$ \\
\hline 1st (24 hours) & 623 & 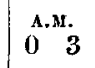 & $\cdot 163$ & $\begin{array}{l}\text { A.M. } \\
219\end{array}$ & $\cdot 505$ & $\begin{array}{l}\text { A.M. } \\
015\end{array}$ & .096 & 435 & 204 & $\begin{array}{l}\text { A. N. } \\
412\end{array}$ \\
\hline 2 nd (12 hours) & $\cdot 456$ & 235 & .089 & 529 & $\cdot 171$ & 125 & .069 & 358 & .200 & 827 \\
\hline 3rd (8 hours)... & $\cdot 430$ & 257 & $\cdot 229$ & 358 & $\cdot 111$ & 117 & .075 & 652 & 327 & 553 \\
\hline 4 th ( 6 hours)... & $2 I \pm$ & 156 & .069 & 112 & .068 & I $4 \mathrm{I}$ & .086 & 218 & .052 & 442 \\
\hline 5 th ( $4 \frac{4}{5}$ hours) & $\cdot 239$ & 112 & .051 & 050 & .072 & 133 & $\cdot 121$ & 040 & $\cdot 148$ & 310 \\
\hline 6th (4 hours)... & .088 & 052 & $\cdot 121$ & 032 & $\cdot 210$ & 037 & $\cdot 239$ & 157 & $\cdot 293$ & 055 \\
\hline
\end{tabular}

The numerous slight shocks which follow a severe earthquake are subject at first to a rapid decline in frequency *. Now, if a simple harmonic series be superposed on a declining linear series, the harmonic analysis of the compound series shows that not only are the amplitude and epoch of the function of the same period changed, but minor harmonic components are also introduced. It is clear therefore that the epochs given above cannot be supposed to agree exactly with those of their physical equivalents. At the same time, the omission of the first one, two, three, and four days in succession from the Gifu and Nagoya records produces no important change in most of the components. Moreover, as will be seen in the next section, the different conditions introduced by the occurrence of a great earthquake endure even when the decline in average frequency of the after-shocks ceases to be sensible

The results for Gifu and Nagoya confirm those obtained by Prof. Omori by a different method of analysis, the 8-hour component being more marked at Gifu, and the 4-hour component at Nagoya. Prof. Omori gives the time of each shock recorded at both places until the end of Nov. 10, those at Nagoya to the nearest second, and those at Gifu generally to the nearest minute. Out of 1257 shocks recorded at Gifu

* F. Omori, Journal of the Coll. of Science, Imp. Univ. Japan, vol. vii. 1894, pp. 111-126; Seismol. Journ. of Japan, vol. iii. 1894, pp. 71-80. See also Natural Science, vol, vi. 1895, pp. 391-397. 
and 572 at Nagoya there are only 175 whose times of occurrence differ by less than a minute; and it does not follow that even all these are identical, for, during the first day or two, shocks were frequently felt at Giiu for several minutes in succession. Though the two stations are less than 14 miles apart, and both are close to the great fault-scarp, it would seem, from the above analysis, that their after-shocks do not originate under quite the same conditions.

8. Gifu: Nov. 11-Dec. 31, 1891, number of earthquakes $839 ; 1892$, number of earthquakes, $865 ; 1893$, number of earthquakes, 272. Nemuro: Apr. 1894-Feb. 1895, number of earthquakes, 347 .

\begin{tabular}{|c|c|c|c|c|c|c|c|c|}
\hline \multirow{2}{*}{$\begin{array}{l}\text { Harmonic } \\
\text { Com ponent. }\end{array}$} & \multicolumn{2}{|c|}{$\begin{array}{c}\text { Gifu, } \\
\text { Nov. 11-Dec.31, } 1891\end{array}$} & \multicolumn{2}{|c|}{ Gifu, 1892.} & \multicolumn{2}{|c|}{ Gifu, 1893} & \multicolumn{2}{|c|}{$\begin{array}{c}\text { Nemuro, } \\
\text { Apr. 1894-Feb. } 1895 .\end{array}$} \\
\hline & Ampl. & $\begin{array}{l}\text { Epoch. } \\
\text { h m }\end{array}$ & Ainpl. & Epoch. & Aropl. & $\begin{array}{l}\text { Epoch. } \\
\mathrm{h} \text { m }\end{array}$ & Ampl. & $\begin{array}{l}\text { Epoch. } \\
\text { h m }\end{array}$ \\
\hline 1st (24 bours) ... & $\cdot 205$ & $\begin{array}{l}\text { A.M. } \\
111\end{array}$ & 007 & ${ }_{5}^{\text {A.M. }} 3$ & $\cdot 106$ & $\begin{array}{c}\text { P.N. } \\
3220\end{array}$ & .062 & $\begin{array}{l}\text { A.M. } \\
029\end{array}$ \\
\hline 2nd $(12$ hours $) \ldots$ & $\cdot 119$ & 255 & $\cdot 171$ & 90 & .087 & $\mid \begin{array}{l}\text { A.M } \\
1043\end{array}$ & 099 & 444 \\
\hline 3rd (8 hours) & $\cdot 156$ & 029 & $\cdot 154$ & 558 & $\cdot 078$ & 126 & $\cdot 217$ & 315 \\
\hline 4th (6 hours) & -018 & 338 & $\cdot 048$ & 033 & $\cdot 138$ & 149 & $\cdot 053$ & 131 \\
\hline 5th (4 $4 \frac{4}{5}$ hours) ... & 076 & 052 & $\cdot 049$ & 438 & $\cdot 085$ & 341 & $\cdot 169$ & 242 \\
\hline 6th (4 hours) ... & $\cdot 137$ & 159 & $\cdot 133$ & 233 & $\cdot 095$ & 159 & $\cdot 205$ & 016 \\
\hline
\end{tabular}

\section{Plilippine Islands.}

9. Manila.-P. Miguel Saderra Masó : La Seismología en Filipinas (Manila, 1895), pp. 100-103.

Duration of record, 1869-1889. Number of earthquakes, $210 *$

\begin{tabular}{|c|c|c|}
\hline $\begin{array}{l}\text { Harmonic } \\
\text { Oomponent. }\end{array}$ & Ampl. & $\begin{array}{l}\text { Epoch } \\
\text { h } \mathrm{m}\end{array}$ \\
\hline 1st ( 24 hours) ... & $\cdot 273$ & $\begin{array}{r}\text { A.M. } \\
1049\end{array}$ \\
\hline and (12 hours)... & $\cdot 136$ & 220 \\
\hline 3rd (8 hours) & $\cdot 210$ & 638 \\
\hline 4th (6 hours) ... & .310 & 422 \\
\hline
\end{tabular}

* The tatal number of shocks in P. Saderra's catalogue is 213, but three of these the exact time is not given. 


\section{Italy.}

10. M. F. de Montessus de Ballore, Arch. des Sci. phys. et nat. vol. xxii. 1889 , tables.

Duration of record: Acireale to Verona, Dec. 1872-1887; Vesuvius, 1863-1884. Number of earth-tremors: Acireale, 364 ; Bologna and S. Luca, 636 ; Cascia, 505 ; Corleone, 584 ; Rocca di Papa, 388 ; Rome, 2346 ; Velletri, 1491 ; Verona, 700 ; Vesuvius, 547 ; Italy, 8177.

In the same table M. de Montessus gives the hourly numbers of tremors at four other observatories (Alvito, Belluno, Narni, and Spinea di Mestre), but the total numbers of tremors are so small $(123,180,144$, and 159) that I have have not made use of them separately. They are, however, included in the total for all Italy.

\begin{tabular}{|c|c|c|c|c|c|c|c|c|}
\hline \multirow{2}{*}{ Obserratory. } & \multicolumn{2}{|c|}{$\begin{array}{l}\text { lst comp. } \\
\text { (2t hours). }\end{array}$} & \multicolumn{2}{|c|}{$\begin{array}{l}\text { 2nd coinp. } \\
\text { (12 hours). }\end{array}$} & \multicolumn{2}{|c|}{$\begin{array}{l}\text { 3rd comp. } \\
\text { ( } 8 \text { hours) }\end{array}$} & \multicolumn{2}{|c|}{$\begin{array}{l}\text { 4th corap. } \\
\text { (6 hours). }\end{array}$} \\
\hline & $\Delta m p l$. & $\begin{array}{l}\text { Epoch. } \\
\text { h } \text { wa }\end{array}$ & Ampl. & $\begin{array}{l}\text { Epoch. } \\
\text { b } \mathbf{m}\end{array}$ & Ampl. & $\begin{array}{c}\text { Epoch. } \\
\mathbf{h} \mathbf{~ m}\end{array}$ & Ampl. & $\begin{array}{l}\text { Epoch } \\
\text { b m }\end{array}$ \\
\hline Acireale & $\cdot 583$ & $\begin{array}{l}\text { P.M. } \\
045\end{array}$ & $\cdot 119$ & 1145 & $\cdot 041$ & $\begin{array}{l}\text { A.M. } \\
017\end{array}$ & $\cdot 143$ & 251 \\
\hline Bologna \& S. Luea & 705 & $\begin{array}{ll}0 & 8\end{array}$ & $\cdot 166$ & 656 & $\cdot 081$ & 741 & .009 & 525 \\
\hline Oascia & .259 & 127 & $\cdot 091$ & 911 & $\cdot 166$ & 438 & $\cdot 230$ & 335 \\
\hline Corleone & 398 & 013 & $\cdot 305$ & 114 & 217 & 316 & .093 & $\ddot{3} 3$ \\
\hline Rocea di Papa & 523 & 1122 & $\cdot 159$ & 1122 & $-3+2$ & 410 & $\cdot 103$ & 244 \\
\hline Rome & 613 & 036 & $\cdot 143$ & 1025 & 097 & ] 37 & 1,00 & 46 \\
\hline Velletri & $\cdot 307$ & 025 & $\cdot 113$ & 110 & 164 & 043 & $\cdot 060$ & 225 \\
\hline Verona & .238 & $1 \begin{array}{ll}11 & 32 \\
8 & 30\end{array}$ & 270 & 107 & $\cdot 137$ & 055 & 366 & 356 \\
\hline Vesuvius & $\cdot 494$ & 011 & $\cdot 371$ & 185 & $\cdot 052$ & 559 & .038 & 343 \\
\hline Italy & -324 & 025 & $\cdot 112$ & 1114 & .045 & 146 & $\cdot 113$ & 347 \\
\hline
\end{tabular}

The nine Italian records thas agree in exhibiting a marked diurnal period, the epoch in seven cases being about noon, and in the other two cases not far from midnight. Reference has already been made to M. de Montessus's explanation of the preponderance of slight tremors during the day. There is much to be said in farour of this explanation. The observatory on Vesuvius is only a few yards from the main road, along which there is a great deal of heavy traffic about midday. During the interval embraced by M. de Montessus's

Phil. Mag. S. 5. Vol. 42. No. 259. Dee. 1896. 2 L 
catalogue the observatory at Rome was situated close to a much-frequented stret. At the various observatories of the second order the arrangement of the recording instrument, I am informed, was not then irreproachable. On the other hand, at Rocca di Papa, Dr. Cancani tells me that the apparatus could not be in any way influenced by accidental or artificial movements on the ground outside. $\mathrm{H}_{\Theta}$ does not, however, attribute the movements of the tromometers to seismic causes so much as to the action of the wind either near to, or at a distance from, the observatory.

This one case, therefore, being free from doubt so far as artificial disturbances are concerned, it becomes unnecessary to reject entirely the results obtained from the other records, especially when the epochs of the principal harmonic components agree so closely, as some of them do, with those derived from the Rocca di Papa register. Moreover, while some variability might be expected in the epoch of the diurnal period if it were due to natural causes, it is difficult to understand how, according to M. de Montessus's explanation, the epoch could ever occur near midnight.

\section{Summary of Results.}

11. The following conclusions may, I think, be drawn from the results of the above analysis:

(1) The reality of the diurnal variation of earthquakefrequency seems to be proved by the approximate agreement in epoch (mean local time) of the first four components for the whole year at Tokio and Manila, and for the winter and summer halves of the year at Tokio.

(2) In ordinary earthquakes there is in nearly every case a marked diurnal period, the maximum generally occurring between 10 A.M. and noon. The semi-diurual period, though less prominent, is also clearly marked, the maximum occurring, as a rule, between 9 A.M. and noon and between 9 P.M. and midnight. Other minor harmonic components are also occasionally important-the first maximum of the eight-hour component probably occurring about 6.30 A.M. and that of the six-hour component about 3 or 4 A.M.; but in these two epochs the results are not always concordant.

(3) Though the materials are insufficient for any general conclusion, a comparison of the results for Tokio and Rocca di Papa seems to show that the slighter disturbances at the latter place are subject to a more marked diurnal periodicity.

(4) In the after-shocks of great earthquakes the diurnal periodicity, as a rule, is strongly pronounced. The maximum of the diurnal period occurs within a few hours after midnight, but the epochs of the other components are subject to 
wide variation. A special feature of after-shocks is the prominence of the eight-hour and four-hour components. After a year or two there is some return to ordinary conditions; but even when the average hourly number of shocks is reduced to one-hundredth of that during the first few days, the characteristics of after-shocks are still perceptible.

\section{Origin of the Diurnal Periodicity of Earthquakes.}

12. The pressure of the atmosphere, either at rest or in motion, has for some time been regarded by seismologists as a cause of earth-tremors. Prof. Milne, who has made a detailed analysis of tremors recorded at Tokio, concludes that they are more frequent with a low than with a high barometer, and with a high than with a low barometric gradient; also, that a majority of the tremors were produced by the action of either local or distant winds upon the surface of the earth, and possibly by their pressure against a neighbouring mountain-range *.

My object is now to inquire how far the larger disturbances considered in this paper are subject to similar laws. If there is any intimate relation between the diurnal variation of earthquake-frequency on the one hand and that of barometric pressure or wind-velocity on the other, it is evident that the epochs of their respective harmonic components should not differ widely; since any distortion of the earth's surface by changes in the distribution of atmospheric pressure must be propagated, both along the surface and downwards, with great velocity.

The records of most value for the purposes of this comparison are: (1) those of ordinary earthquakes at Tokio, Manila, and Rocca di Papa ; and (2) those of after-shocks at Kumamoto, Gifu, Nagoya, Chiran, and Nemuro.

13. Taking, first, the diurnal variation of barometric pressure and seismic frequency, it will be seen that the only approximate agreement in epoch is in the second and fourth components at Tokio and the second at Rocca di Papa. The epochs of the first component differ by as much as eight or nine hours at both places.

* "Earth-Tremors in Central Japan," Japan Seismol. Soc. Trans. vol. xi. 1887, pp. 1-78, vol, xiii. 1890, pp. 7-19; "Farth-Tremors and the Wind," Roy. Met. Soc. Journ. vol. xiv. 1888, pp. 64-72. It should be mentioned, however, that P. Camillo M. Melzi has alrived at different conclusions from his analysis of the tromometric records at Florence. See especially his memoir, "Nuove osservazioni sull' independenza dal vento nei moti tromometriei nei pendoli isolati," Pontif. Accad. dei Nuovi Lincei, Mem. vol, v. 1889, pp. 3-39. 


\begin{tabular}{|c|c|c|c|c|c|c|c|c|c|c|}
\hline \multirow{2}{*}{\multicolumn{3}{|c|}{$\begin{array}{c}\text { Barometric } \\
\text { Pressure. }\end{array}$}} & \multicolumn{2}{|c|}{$\begin{array}{l}\text { Ist comp. } \\
\text { (24 hours). }\end{array}$} & \multicolumn{2}{|c|}{$\begin{array}{l}\text { 2nd comp. } \\
\text { (12 hours). }\end{array}$} & \multicolumn{2}{|c|}{$\begin{array}{l}3 \text { rd comp. } \\
\text { ( } 8 \text { hours). }\end{array}$} & \multicolumn{2}{|c|}{$\begin{array}{l}\text { 4th comp. } \\
\text { (B hours). }\end{array}$} \\
\hline & & & $\underset{\min .}{\text { Ainpl. }}$ & $\begin{array}{c}\text { Epoch. } \\
\text { h } \mathbf{~ w}\end{array}$ & $\begin{array}{c}\text { Ampl. } \\
\text { nnm. }\end{array}$ & $\begin{array}{c}\text { Epoch. } \\
\text { h } \mathrm{m}\end{array}$ & $\underset{\text { nimpl. }}{\text { Aimpl. }}$ & $\begin{array}{c}\text { Epoch } \\
\text { h } \mathrm{m}\end{array}$ & $\underset{\text { nimo. }}{\text { Anapl. }}$ & $\underset{\text { Epoch. }}{\text { E } \mathrm{m}}$ \\
\hline Tokio & bol & ear). & $\cdot 52$ & $\begin{array}{l}\text { A.M. } \\
122\end{array}$ & -54 & ${ }_{9}^{\text {A.M. }} 5$ & 07 & $\begin{array}{l}\mathrm{A}+\mathrm{M} . \\
243\end{array}$ & $\cdot 03$ & $\begin{array}{l}\text { A.M. } \\
337\end{array}$ \\
\hline " & inte & & 67 & 054 & 61 & 856 & $\cdot 19$ & 125 & .03 & 357 \\
\hline " & imn & c) $\ldots$ & $\cdot 41$ & 22 & $\cdot 48$ & 922 & .03 & 522 & $\cdot 01$ & 30 \\
\hline Milan & hol & year) & $\cdot 18$ & $\begin{array}{ll}37\end{array}$ & 36 & 959 & .01 & 240 & $\cdots$ & $\cdots$ \\
\hline Naples & " & 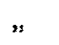 & .09 & 057 & 31 & 1013 & .03 & 218 & 01 & 39 \\
\hline Turin & $"$ & $"$ & $\cdot 25$ & 23 & $\cdot 39$ & 959 & .04 & 134 & $\cdot 02$ & 334 \\
\hline
\end{tabular}

\begin{tabular}{|c|c|c|c|c|c|c|c|c|}
\hline \multirow{2}{*}{ Wind-Velocity. } & \multicolumn{2}{|c|}{$\begin{array}{l}\text { 1st comp. } \\
\text { (24 hours). }\end{array}$} & \multicolumn{2}{|c|}{$\begin{array}{l}\text { 2nd comp. } \\
\text { (12 hours). }\end{array}$} & \multicolumn{2}{|c|}{$\begin{array}{l}\text { 3rd comp. } \\
\text { ( } 8 \text { hours). }\end{array}$} & \multicolumn{2}{|c|}{$\begin{array}{l}\text { 4th comp. } \\
\text { (6 hulurs). }\end{array}$} \\
\hline & $\begin{array}{c}\text { Ampl. } \\
\text { ni. } \\
\text { per sec. }\end{array}$ & $\begin{array}{c}\text { Epoch. } \\
\text { h m }\end{array}$ & $\begin{array}{c}\text { Ampl. } \\
\text { m. } \\
\text { per sec. }\end{array}$ & $\begin{array}{c}\text { Epoch. } \\
\text { h m }\end{array}$ & $\begin{array}{c}\text { Ampl. } \\
\text { m. } \\
\text { per sec. }\end{array}$ & $\left\{\begin{array}{l}\text { Epoch. } \\
\text { h m }\end{array}\right.$ & $\begin{array}{c}\text { Ampl. } \\
\text { m. } \\
\text { per sec. }\end{array}$ & $\begin{array}{l}\text { Epoch } \\
\text { h m }\end{array}$ \\
\hline Tokio (whole year). & .86 & $\begin{array}{l}\text { P.M. } \\
042\end{array}$ & $\cdot 24$ & $\begin{array}{l}\text { A.M. } \\
152\end{array}$ & $\cdot 02$ & 623 & $\cdot 0 \tilde{0}$ & 348 \\
\hline " (winter) ...... & -48 & 1156 & 25 & 17 & -04 & 523 & $\cdot 06$ & 334 \\
\hline " (summer) ... & $1 \cdot 25$ & 059 & $\cdot 26$ & 235 & .03 & 025 & $\cdot 40$ & 46 \\
\hline Manila (whole year) & $2 \cdot 01$ & 044 & -51 & 150 & .06 & 149 & .08 & 3 53 \\
\hline
\end{tabular}

In the case of wind-velocity the agreement in epoch is much closer, especially for the third and fourth components at Tokio. The epochs of the first and second seismic components at the same place, however, precede those of windvelocity by as much as two or three hours. At Manila the epoch of the first component of seismic frequency precedes that of wind-velocity by about two hours, and the epoch of the second component of the former follows that of the latter by half-an-hour.

The diurnal variation of barometric gradient between Tokio and Nagano (112 miles W. $30^{\circ} \mathrm{N}$. of Tokio) seems too slight to produce such important effects, though the epochs of its harmonic components do nat differ widely from thase of windvelocity*.

* I am indebted to Prof. Omori for copies of the tables of the hourly means of barometric pressure at Tokio and Nagano published by the 


\begin{tabular}{|c|c|c|}
\hline Barometric Gradient. & $\begin{array}{c}\text { Ampl. } \\
\text { min. } \\
\text { per } 312 \text { miles. }\end{array}$ & $\begin{array}{c}\text { Epocb. } \\
\text { h } m\end{array}$ \\
\hline 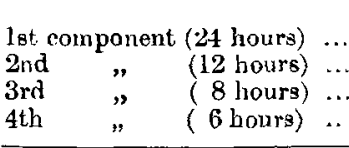 & $\begin{array}{l}\cdot 106 \\
.057 \\
.010 \\
.006\end{array}$ & $\begin{array}{rl}\text { P. } & \\
0 & 50 \\
10 & 5 \\
5 & 3 \\
4 & 0\end{array}$ \\
\hline
\end{tabular}

With regard to the after-shocks of Japanese earthquakes, the records are of such short duration that satisfactory results can only be obtained by a detailed comparison during the intervals over which they extend. It is worthy of notice, however, that the epoch of the first seismic component occurs with some persistence early in the day, and does not differ very greatly from that of the first component for barometric pressure.

It seems evident, therefore, that we cannot attribute the diurnal variation of seismic frequency exclusively to that of barometric pressure or of wind-velocity. But it is not improbable that it may result from a combination of both phenomena; that the diurnal periodicity of ordinary earthquakes may be due chiefly to that of wind-velocity, and the diurnal periodicity of after-shocks chiefly to that of barometric pressure. In support of this suggestion, it may be mentioned that the amplitudes of the first component of windvelocity and earthquake-frequency at Tokio are both greater in summer than in winter, and that the same amplitudes for the whole year are both greater at Manila than at Tokis.

In the case of after-shocks, a reason may be given for the efficacy of barometric pressure if, as seems not improbable, the principal earthquakes were due to the sudden elevation of one rock-mass adjoining a fault. In a movement so abrupt as this mnst be, the disturbed mass would almost certainly overshoot its position of equilibrium, and immediately afterwards would begin to settle back to it by a succession of minor slips, at first numerous but gradually becouning less frequent along the whole line of displacement. In such a condition the elevated rock-mass would, in sonie part or other, be constantly on the point of giving way, and a slight increase of barometric pressure would probably be sufficient to precipitate a slip resulting in an after-shosk.

Imperial Meteorolugical Othice at 'lokio. The hourly means fir the ltalian stations are given in Buchan's 'Atmospheric Crreulation,' pp. 17, 18. The hoully means of wind-yelocity for Tokio are obtained from the 'Report of the Meteorological Observations for the ten years 1876-1885 made at the Imperial Metearological Observatory of Tokio'; those for Manila from the 'Osservatorio Meteorologico de Manila, Observaciones verificadas' (1890-9:3). 
Dr. C. Davison on the Diurnal

\begin{tabular}{|c|c|c|}
\hline & : & 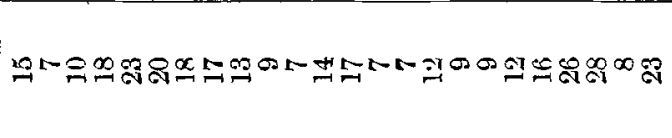 \\
\hline & : & 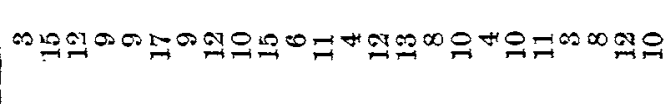 \\
\hline & 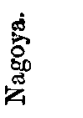 & 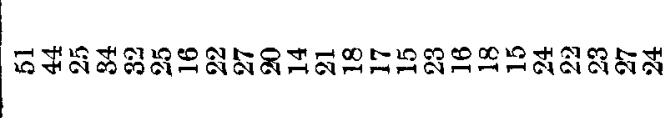 \\
\hline & 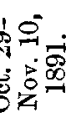 & 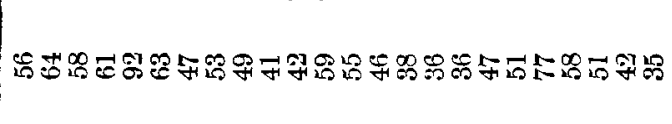 \\
\hline & : & 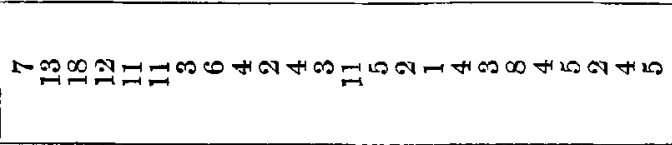 \\
\hline & 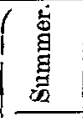 & 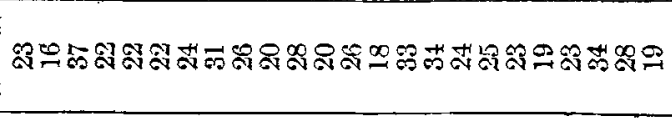 \\
\hline 离 & 要 & 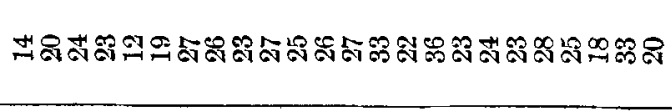 \\
\hline & 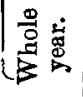 & 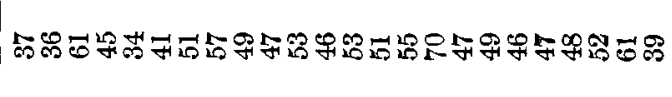 \\
\hline \multirow{3}{*}{ 串 } & 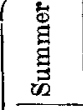 & 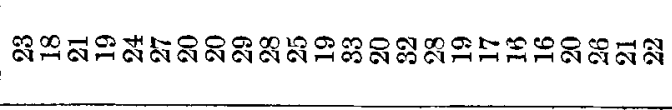 \\
\hline & 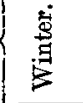 & 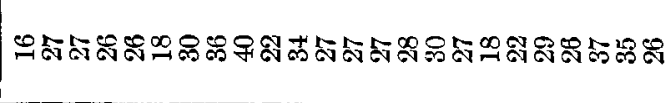 \\
\hline & 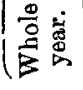 & 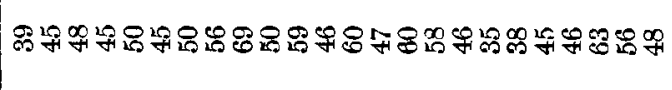 \\
\hline \multicolumn{2}{|c|}{ 意 } & 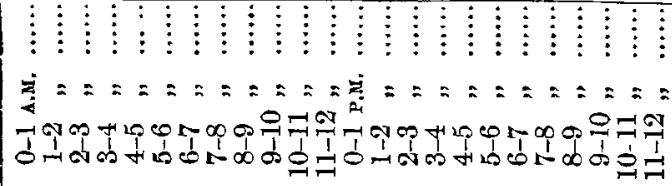 \\
\hline
\end{tabular}


Periodicity of Earthquakes.

\begin{tabular}{|c|c|}
\hline 青 & 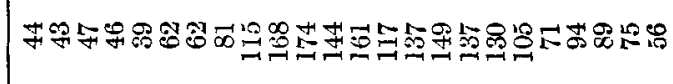 \\
\hline 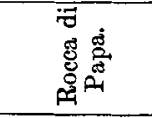 & 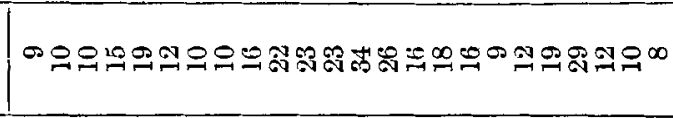 \\
\hline 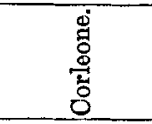 & 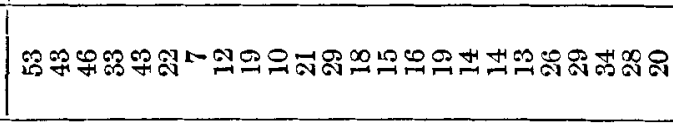 \\
\hline 惖 & 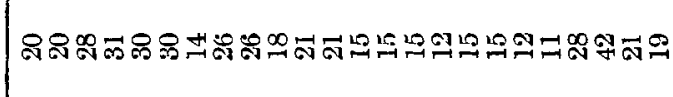 \\
\hline 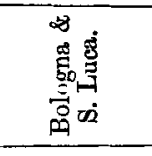 & 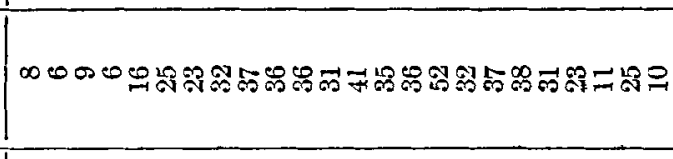 \\
\hline 竓 & 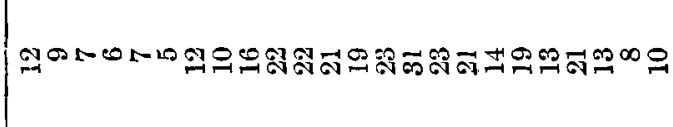 \\
\hline 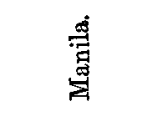 & 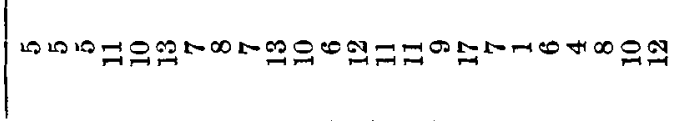 \\
\hline 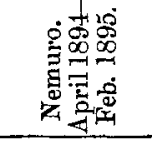 & 品 \\
\hline 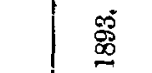 & 멱버 \\
\hline 递突 & 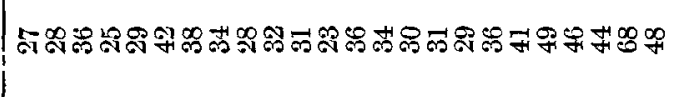 \\
\hline 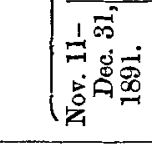 & 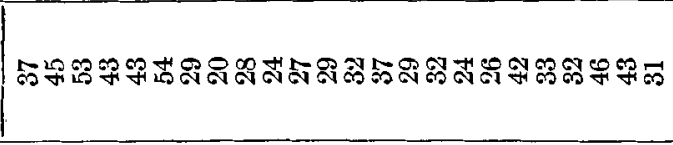 \\
\hline 官 & 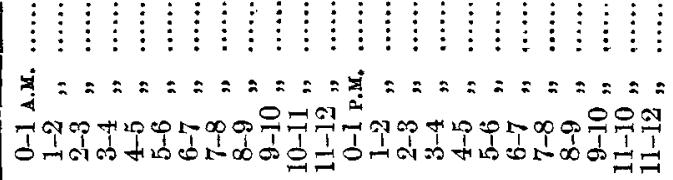 \\
\hline
\end{tabular}


Mr. W. Sutherland on Thermal

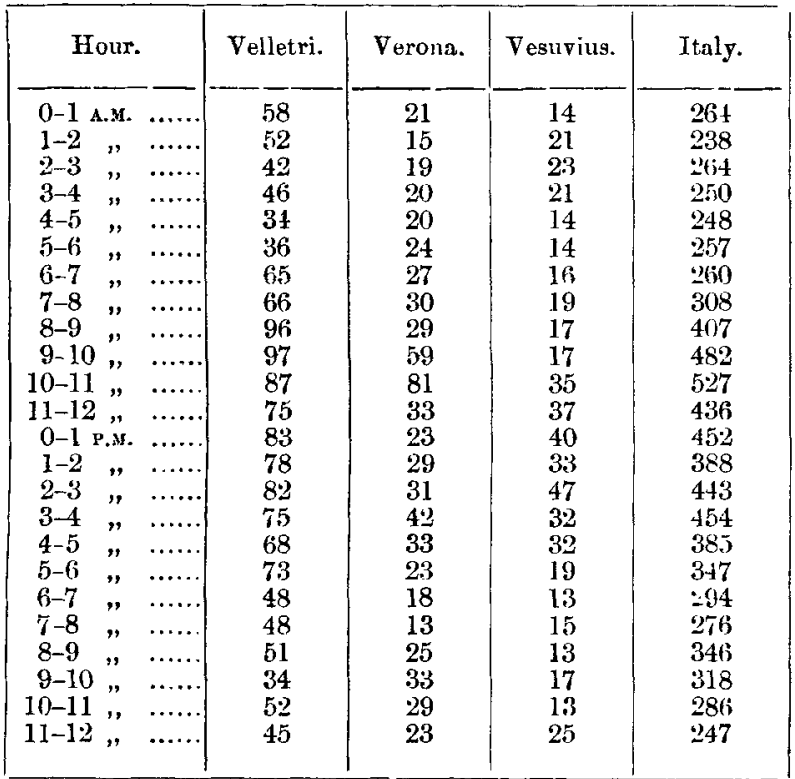

XLIX. Thermal Transpiration and Radiometer Motion. By William Sutherland*.

[Continued from p. 391.]

PART II.-Radiometer Motion.

REYNOLDS, in treating of radiometer motion in connexion with his discovery of thermal transpiration, showed that fundamentally both phenomena are tracealle to the same general cause: the object of the rest of this paper is to bring out this fact more clearly, and to establish theoretically the general laws of radiometer motion for comparison with the experimental results of Crookes and Pringsheim.

In the theory of thermal transpiration, we have seen that under suitable conditions the rariation of temperature along a passage through a porous plate can produce a certain difference between the pressures at its hot and cold ends, and therefore the solid wall of the passage must be exerting a tangential force $\mathrm{F}$ from cold to hot, such that, $\mathrm{R}$ being the mean radius of the passage,

$$
\mathrm{F}=\pi \mathbf{R}^{2}\left(p_{2}-p_{3}\right),
$$

and, accordingly, the gas in the passage exerts a tangential

* Communicated by the Author. 